\title{
Operational mapping of atmospheric nitrogen deposition to the Baltic Sea
}

\author{
O. Hertel, C. Ambelas Skjøth, J. Brandt, J. H. Christensen, L. M. Frohn, and J. Frydendall
}

National Environmental Research Institute, Department of Atmospheric Environment, P.O. Box 358, Frederiksborgvej 399, 4000 Roskilde, Denmark

Received: 17 October 2002 - Published in Atmos. Chem. Phys. Discuss.: 8 July 2003

Revised: 7 November 2003 - Accepted: 17 November 2003 - Published: 28 November 2003

\begin{abstract}
A new model system for mapping and forecasting nitrogen deposition to the Baltic Sea has been developed. The system is based on the Lagrangian variable scale transport-chemistry model ACDEP (Atmospheric Chemistry and Deposition model), and aims at delivering deposition estimates to be used as input to marine ecosystem models. The system is tested by comparison of model results to measurements from monitoring stations around the Baltic Sea. The comparison shows that observed annual mean ambient air concentrations and wet depositions are well reproduced by the model. Diurnal mean concentrations of $\mathrm{NH}_{\mathrm{x}}$ (sum of $\mathrm{NH}_{3}$ and $\mathrm{NH}_{4}^{+}$) and $\mathrm{NO}_{2}$ are fairly well reproduced, whereas concentrations of total nitrate (sum of $\mathrm{HNO}_{3}$ and $\mathrm{NO}_{3}^{-}$) are somewhat overestimated. Wet depositions of nitrate and ammonia are fairly well described for annual mean values, whereas the discrepancy is high for the monthly mean values and the wet depositions are rather poorly described concerning the diurnal mean values. The model calculations show that the annual atmospheric nitrogen deposition has a pronounced south-north gradient with depositions in the range about $1.0 \mathrm{~T} \mathrm{~N} \mathrm{~km}{ }^{-2}$ in the south and $0.2 \mathrm{~T} \mathrm{~N} \mathrm{~km}^{-2}$ in the north. The results show that in 1999 the maximum diurnal mean deposition to the Danish waters appeared during the summer in the algae growth season. For the northern parts of the Baltic the highest depositions were distributed over most of the year. Total deposition to the Baltic Sea was for the year 1999 estimated to $318 \mathrm{kT} \mathrm{N}$ for an area of $464406 \mathrm{~km}^{2}$ equivalent to an average deposition of $684 \mathrm{~kg} \mathrm{~N} / \mathrm{km}^{2}$.
\end{abstract}

Correspondence to: O. Hertel

(ole.hertel@dmu.dk)

\section{Introduction}

From the beginning of the 19th century and up to the middle of the 1980's, the nutrient input of nitrogen and phosphorous to the Baltic increased by a factor of four and eight, respectively (Larsson et al., 1985). Oxygen deficits and subsequent death of fish and benthic fauna became frequent phenomena over the same period of time (Meyer-Reil and Köster, 2000). These phenomena are directly linked to large algae production resulting from the high nutrient inputs (Rydberg et al., 1990), where nitrogen generally is considered to be the limiting factor in the coastal region (Paerl, 1995). When the algae production is high, a result is that large amounts of dead algae deposit at the bottom, and the oxygen in the bottom water of the sea is consumed in the degradation of the algae. As an example, Møhlenberg (1999) has estimated that a 25\% reduction in nitrogen to the Danish estuaries would lead to a $50 \%$ reduction in the number of days with severe oxygen depletion.

Besides playing a significant role in oxygen depletion episodes, it has been suggested in a number of papers that high nutrient inputs are responsible for an increased frequency of episodes with high concentrations of algae that are harmful to the health of humans and animals (Rydberg et al., 1990; Rosenberg et al., 1990; Spokes et al., 1993; Richardson, 1997; Møhlenberg, 1999; Meyer-Reil and Köster, 2000). However, the identification of harmful algae blooms is complex and there are no long time series of the occurrence in such episodes. A documentation of an increase in occurrence and a link between this increase and high anthropogenic nutrient inputs has therefore not yet been given (Richardson, 1997).

Despite of its clear significance for the overall nitrogen loads to coastal waters like the Baltic Sea, the atmospheric input has often been roughly determined and given little focus. Rosenberg et al. (1990) estimated that about 50\% of the nitrogen load of the overall Baltic Sea arises from 
atmospheric deposition. The main part of the atmospheric deposition is related to wash out of aerosol phase nitrogen compounds during rain events. Lindfors et al (1993) found in field studies that dry deposition contributed to between 10 and $30 \%$ of the atmospheric nitrogen input to the Baltic Sea. It has been suggested that events of high nutrient inputs resulting from wash out of atmospheric nitrogen compounds during rain events may cause short-term blooms of algae under certain circumstances (Spokes et al., 1993; 2000). There is thus a need for high quality and high-resolution atmospheric nitrogen deposition estimates for use as input for marine ecosystem models.

In this paper a newly developed operational model system for producing high-resolution mapping as well as forecasts of nitrogen deposition to the Baltic Sea is presented. Data from this system will in turn be used as input for marine ecosystem models and the observed impact on the results obtained from the marine ecosystem models will be published in subsequent papers.

\section{The prognostic model system}

Since summer 1998 the THOR forecasting system has been operated at the National Environmental Research Institute (NERI) (Brandt et al., 2000; 2001a; 2001b). The THOR system produces 3-days forecasts of air pollution on regional scale down to local scale with focus on the Danish area. Within the THOR system, the Eta model (Nickovic et al., 1998) provides the meteorological forecasts that serve as input for a chain of air pollution models: The regional scale Danish Eulerian Operational Model (DEOM) (Brandt et al., 2001a; a validation is given in Tilmes et al., 2001), the urban scale Urban Background Model (UBM) (Berkowicz, 2000a) and the street scale Operational Street Pollution Model (OSPM) (Berkowicz et al., 1997; Berkowicz, 2000b). The ACDEP (Atmospheric Chemistry and Deposition) model (Hertel et al., 1995) has now been coupled operationally to this system.

The ACDEP is a variable scale trajectory model where transport, chemical transformations and depositions are computed following an air parcel along 96-h back-trajectories. The air parcel is divided into 10 vertical layers from the ground and up to $2 \mathrm{~km}$ height (remaining vertical grids are defined at 25, 138, 343, 591, 858, 1136, 1420 and $1708 \mathrm{~m}$ ). Exchange of species (gases and aerosols) between the layers is described by the diffusion equation using first-order approximation (K-theory). For ozone an influx from the free troposphere is assumed at the top of the model domain, using a prescribed seasonal variation in ozone concentrations in the free troposphere and an average exchange velocity. For all other compounds exchange with the free troposphere is considered negligible and therefore disregarded. Transport of the entire air column is assumed to follow the $\sigma$-level 0.925 wind (approximately $800 \mathrm{~m}$ above ground) disregarding wind turning with height.

The dry deposition velocity is described with the resistance method as given in Wesely and Hicks (1977). The aerodynamic resistance is computed with a standard method based on the relationship between wind speed, stability and the friction velocity. The laminar boundary layer resistance is given as a function of friction velocity, surface roughness and a surface roughness parameter of the specie. For land surfaces a constant surface roughness of $30 \mathrm{~cm}$ is assumed. For sea surfaces a slightly modified Charnock's formula is applied (Lindfors et al., 1991; Asman et al., 1994) so that the interdependence between friction velocity and sea surface roughness is taken into account. The roughness parameter for gaseous compounds is computed using formulas proposed by Brutsaert (1982), while for particles a method based on Slinn and Slinn (1980) is applied. The surface resistance over sea is modelled taking into account solubility and reactivity of the species in water (Asman et al., 1994).

The wet deposition is calculated taking into account both in-cloud and below cloud scavenging applying specific scavenging coefficients for the compounds in the model. It is assumed that in-cloud scavenging takes place in the model layers between $250 \mathrm{~m}$ and $2 \mathrm{~km}$, while below cloud scavenging takes place in the layers below $250 \mathrm{~m}$. The scavenging coefficients are computed taking into account solubility and wet phase reactivity (Hertel et al., 1995 and references herein). Depending on the rain intensity (obtained from the Eta model) it is assumed that a larger or smaller fraction of a grid cell is covered by rain. This fraction is calculated applying a method described in Sandnes (1993). Observations have revealed that in Denmark the cloud base in average is found at approximately $80 \mathrm{~m}$ during precipitation events (Asman et al., 1994). Although clouds may easily be situated above the model domain, clouds at higher altitude are assumed without impact on the wet deposition processes.

The chemical module in the model is an extended version of the Carbon Bond Mechanism IV (CBM-IV) (Gery et al., 1989a,b) containing 35 chemical species and 80 chemical reactions. The extensions of the mechanism concern the description of ammonia and its reaction products. The numerical solver for the chemistry is the Eulerian Backward Iterative (EBI) method (Hertel et al., 1993), which has recently been considered to have the best accuracy/speed ratio among a variety of commonly applied solvers (Huang and Chang, 2001). However, the chemistry and the vertical diffusion are now solved simultaneously using the EBI method. This modification of the numerical treatment reduced the calculation time and improved the numerical accuracy considerably. The temperature and cloud cover data provided from the Eta model are used in the calculation of chemical reaction rates. Cloud cover is here used for computing solar radiation for determining photo dissociation rates for relevant species in the chemical mechanism. Similarly relative humidity is used for calculating distribution of nitrogen species 

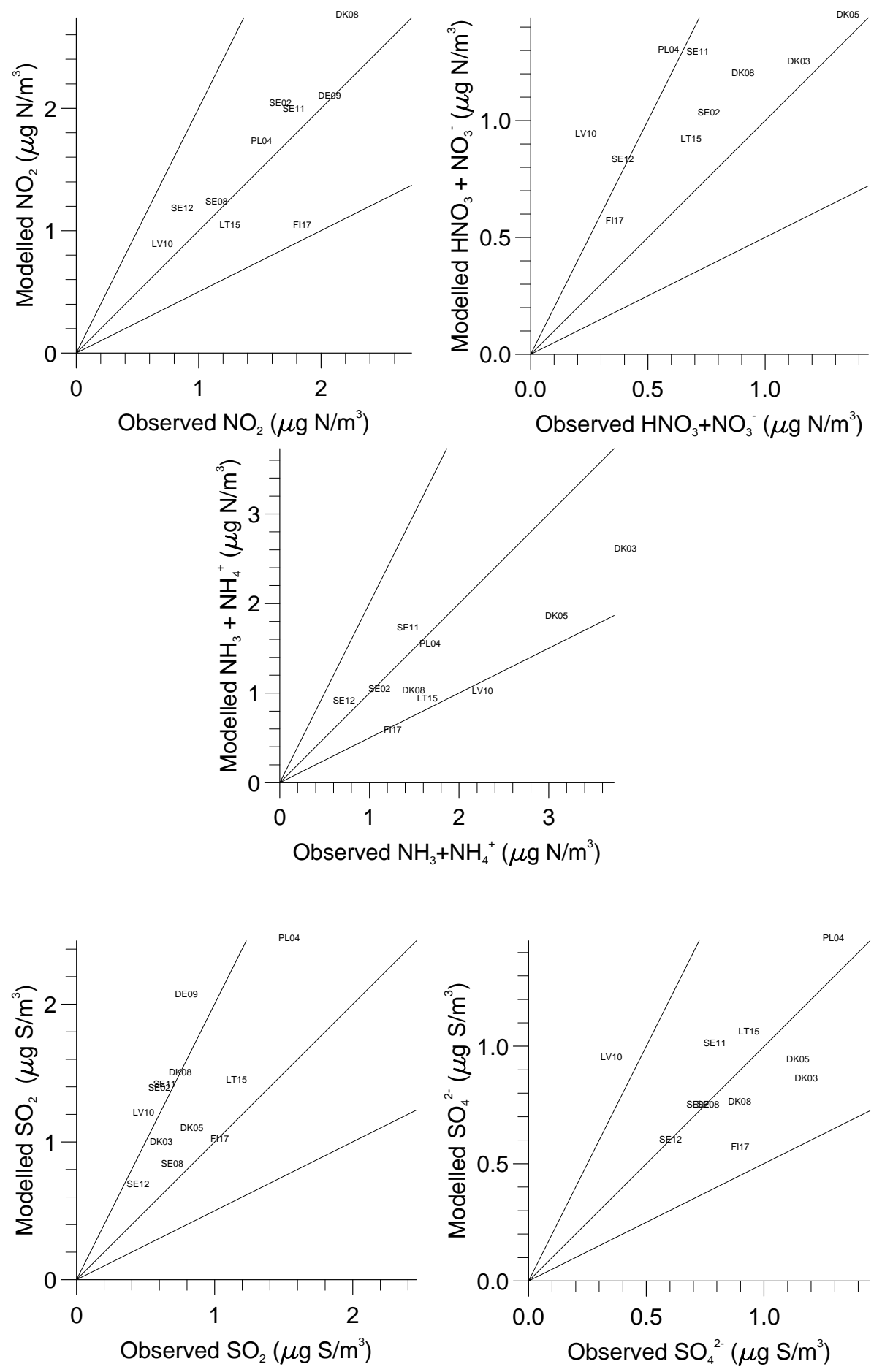

Fig. 1. Comparison between observed and calculated annual mean concentrations in 1999 of nitrogen dioxide, the sum of nitric acid and aerosol phase nitrate, and $\mathrm{NH}_{\mathrm{x}}$ (the sum of $\mathrm{NH}_{3}$ and $\mathrm{NH}_{4}^{+}$) at the 16 selected stations in the EMEP programme. The station codes in the figure are explained in Appendix 1 and straight lines indicate 1:1, $1: 2$ and $2: 1$, respectively.

Fig. 2. Comparison between observed and calculated annual mean concentrations in 1999 of sulphur dioxide and sulphate at the 16 selected stations in the EMEP programme. The station codes in the figure are explained in Appendix 1 and straight lines indicate $1: 1$, $1: 2$ and $2: 1$, respectively.

between gas phase and aerosol phase e.g. formation of ammonium nitrate from nitric acid and ammonia (see details in Hertel et al., 1995). Cloud processing of gas phase to aerosol phase compounds e.g. $\mathrm{SO}_{2}$ conversion to sulphate, has been parameterised in a simplified way and is therefore not linked directly to cloud data from Eta (again details may be found in Hertel et al., 1995).
Accounting for horizontal dispersion in Lagrangian models requires analysis of many trajectories, which is highly computer demanding. A parameterisation has therefore been implemented to indirectly account for horizontal dispersion (Hertel et al., 1995). Under ideal conditions a plume grows by $1 / 10$ of the travel distance from a source point (Hanna et al., 1982). The emissions received by the air parcel are 


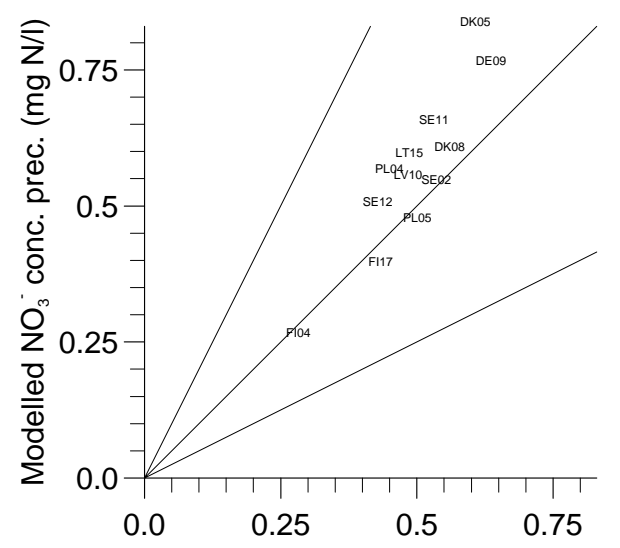

Observed $\mathrm{NO}_{3}$ conc. prec. (mg N/l)
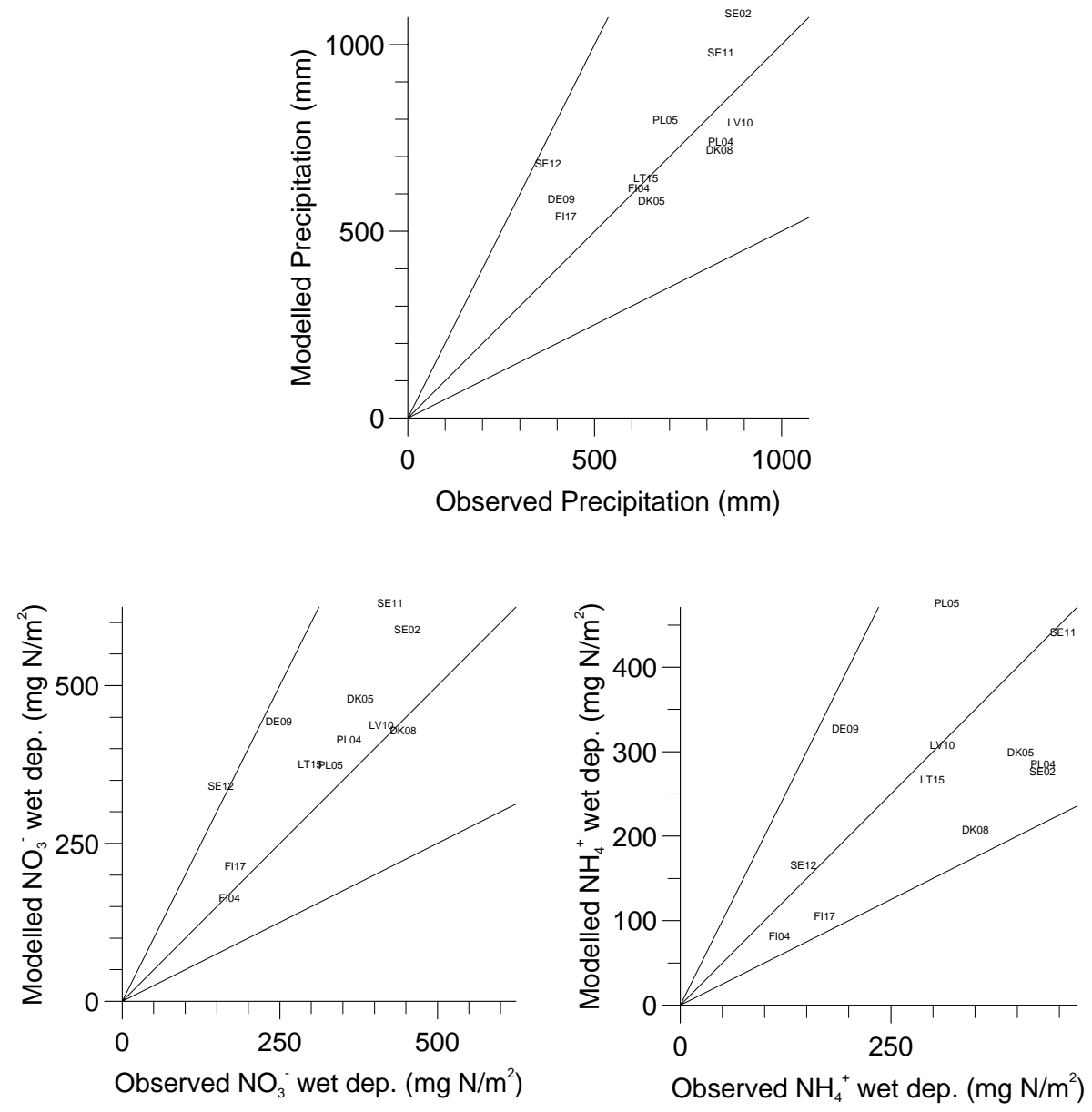

Fig. 3. Comparison between observed and calculated annual mean nitrate and ammonium concentrations in 1999, and of observed and calculated precipitation at the 16 selected stations in the EMEP programme. The station codes in the figure are explained in Appendix 1 and straight lines indicate $1: 1,1: 2$ and $2: 1$, respectively.
Fig. 4. Comparison between observed and calculated annual mean wet deposition of nitrate and ammonium in 1999 at the 16 selected stations in the EMEP programme. The geographic location of the stations in the figure is given in Appendix 1 and straight lines indicate $1: 1$, $1: 2$ and $2: 1$, respectively. therefore averaged over an area around the centreline of the trajectory. This area has the width of $1 / 10$ of the remaining distance along the trajectory to the receptor point, and thereby horizontal dispersion is indirectly accounted for.

In the operational set up, the ACDEP model uses 96-h back-trajectories. Trajectories are computed from the Eta wind fields and stored with two-hourly steps between positions along the trajectories and for arrival times each $6 \mathrm{~h}$ at 00:00, 06:00, 12:00 and 18:00 h. Meteorological parameters for the calculations are provided from the Eta model on spa- tial resolution of approximately $39 \mathrm{~km} \times 39 \mathrm{~km}$ and temporal resolution of $1 \mathrm{~h}$. The following meteorological parameters are used: mixed layer wind speed, surface layer wind speed, mixing height, cloud cover, relative humidity, precipitation, surface temperature, mixed layer temperature, surface heat flux and surface momentum. At the beginning of the trajectory the model column is given a set of initial concentrations. ACDEP was previously initialised with monthly mean background concentrations provide from calculations with the DEM (Zlatev et al., 1992). In this version, however, the 
Table 1. Comparison of observed and modelled ambient air concentrations $\left(\mu \mathrm{g} \mathrm{N} / \mathrm{m}^{3}\right.$ for the nitrogen compounds and $\mu \mathrm{g} \mathrm{S} / \mathrm{m}^{3}$ for the sulphur compounds), concentrations in precipitation $(\mu \mathrm{g} / \mathrm{l})$ and precipitation $(\mathrm{mm})$ at the 16 selected EMEP stations situated around the Baltic Sea. Comparisons of annual mean values for the years 1999. The number of stations is indicated by $n$.

\begin{tabular}{|c|c|c|c|c|c|c|c|c|}
\hline \multirow[t]{2}{*}{ Compound } & \multirow[t]{2}{*}{ Correlation } & \multicolumn{2}{|c|}{ Maximum } & \multicolumn{2}{|c|}{ Minimum } & \multicolumn{2}{|c|}{ Mean } & \multirow[t]{2}{*}{$n$} \\
\hline & & Obs. & Mod. & Obs. & Mod. & Obs. & Mod. & \\
\hline $\mathrm{NO}_{2}$ & 0.78 & 2.12 & 2.74 & 0.62 & 0.87 & 1.42 & 1.58 & 10 \\
\hline $\mathrm{HNO}_{3}+\mathrm{NO}_{3}^{-}$ & 0.75 & 1.30 & 1.44 & 0.19 & 0.56 & 0.67 & 1.07 & 10 \\
\hline $\mathrm{NH}_{3}+\mathrm{NH}_{4}^{+}$ & 0.80 & 3.73 & 2.58 & 0.59 & 0.56 & 1.73 & 1.30 & 10 \\
\hline $\mathrm{SO}_{2}$ & 0.65 & 1.46 & 2.46 & 0.37 & 0.67 & 0.72 & 1.33 & 12 \\
\hline $\mathrm{SO}_{4}^{2-}$ & 0.47 & 1.25 & 1.45 & 0.31 & 0.56 & 0.82 & 0.87 & 11 \\
\hline Wet $\mathrm{NH}_{4}^{+}$ & 0.65 & 0.63 & 0.60 & 0.18 & 0.13 & 0.44 & 0.37 & 12 \\
\hline Wet $\mathrm{NO}_{3}^{-}$ & 0.90 & 0.61 & 0.83 & 0.26 & 0.26 & 0.47 & 0.56 & 12 \\
\hline Wet $\mathrm{SO}_{4}^{2-}$ & 0.44 & 0.76 & 0.92 & 0.29 & 0.22 & 0.59 & 0.62 & 12 \\
\hline Precipitation & 0.70 & 855 & 1072 & 339 & 530 & 640 & 719 & 12 \\
\hline
\end{tabular}

initial concentrations are provided on an hourly time resolution from the DEOM model calculations performed within the operational THOR system.

Atmospheric nitrogen and sulphur depositions to Danish land and sea surfaces are calculated with the ACDEP model on routine basis within the Danish National Background Monitoring Programme (DNBMP) (Ellermann et al., 2002). The calculations in DNBMP are performed for 233 receptor points in a $30 \mathrm{~km} \times 30 \mathrm{~km}$ grid and the results are carefully validated by comparison with measurements from the Danish monitoring stations. In the present work the receptor net from DNBMP has been extended to cover the entire Baltic Sea area. This new receptor net contains in total 690 receptor points. Within the DNBMP the ACDEP model is operated in hind cast mode only, but in the present calculations for the Baltic Sea, the calculations are performed in both hind cast and forecast mode. The forecast computations are performed at 05:00 each day, the results are stored, and selected results are automatically uploaded to an FTP server. Approximately half an hour later they are available at the FTP server for the institutes that will run the marine ecosystem models.

\section{Validation of the model}

Model results have been compared to measurements from the EMEP monitoring stations around the Baltic Sea. The comparison is performed for 1999 since input data for the ACDEP calculations obtained from the THOR system is available only for the year 1999 and forward, and currently the most recent available monitoring data from EMEP are from 1999. The aim of the performed comparison is to explore the ability of the model to reproduce annual, monthly and diurnal mean values observed in the Baltic Sea area. The comparison is carried out for all relevant wet depositions and ambient air concentrations. In the DNBMP the ACDEP model has only been compared to monitoring data on monthly and annual averages. However, the presented model system aims at producing data with a time resolution sufficient for describing nitrogen inputs on a time scale at which algal blooms take place. Such blooms may build up within a few days (Spokes et al., 1993).

\subsection{Annual mean values}

The comparison on annual mean basis is shown in Table 1. The comparisons show that the model tends to overestimate annual mean concentrations of nitrogen dioxide (about $10 \%$ in average) and total nitrogen (sum of $\mathrm{HNO}_{3}$ and $\mathrm{NO}_{3}^{-}$) (about $40 \%$ in average), whereas $\mathrm{NH}_{\mathrm{x}}$ (sum of $\mathrm{NH}_{3}$ and $\mathrm{NH}_{4}^{+}$) is underestimated (about $20 \%$ in average) (see also the graphical presentation in Fig. 1). The correlation between observed and computed concentrations is, however, in general reasonably high for all three species $(0.78,0.75$ and 0.80 , respectively) (Table 1). A good correlation indicates that the spatial distribution of the concentrations is described fairly well.

Sulphate plays an important role in the atmospheric transport of ammonium. On average the model reproduces annual sulphate levels reasonably well, but the correlation between modelled and observed sulphate concentrations is relatively poor (0.47) (Table 1). Somewhat better correlation is obtained for sulphur dioxide (0.65), but here the concentrations are generally overestimated (see also Fig. 2).

The atmospheric nitrogen input to the North Sea is strongly dominated (about $80 \%$ on annual basis) by the contribution from wet deposition (Hertel et al., 2002). The model comparison shows that nitrate concentrations in precipitation (correlation of 0.90) are well reproduced (Table 1 and Fig. 3), although there is a tendency for a slight overestimation (in average about 20\%). The correlation is smaller but still fairly good for ammonium concentrations in precipitation (0.65), but here with a similar tendency for 


$$
\mathrm{NH}_{3}+\mathrm{NH}_{4}^{+}\left(\mu \mathrm{g} \mathrm{N} / \mathrm{m}^{3}\right)
$$
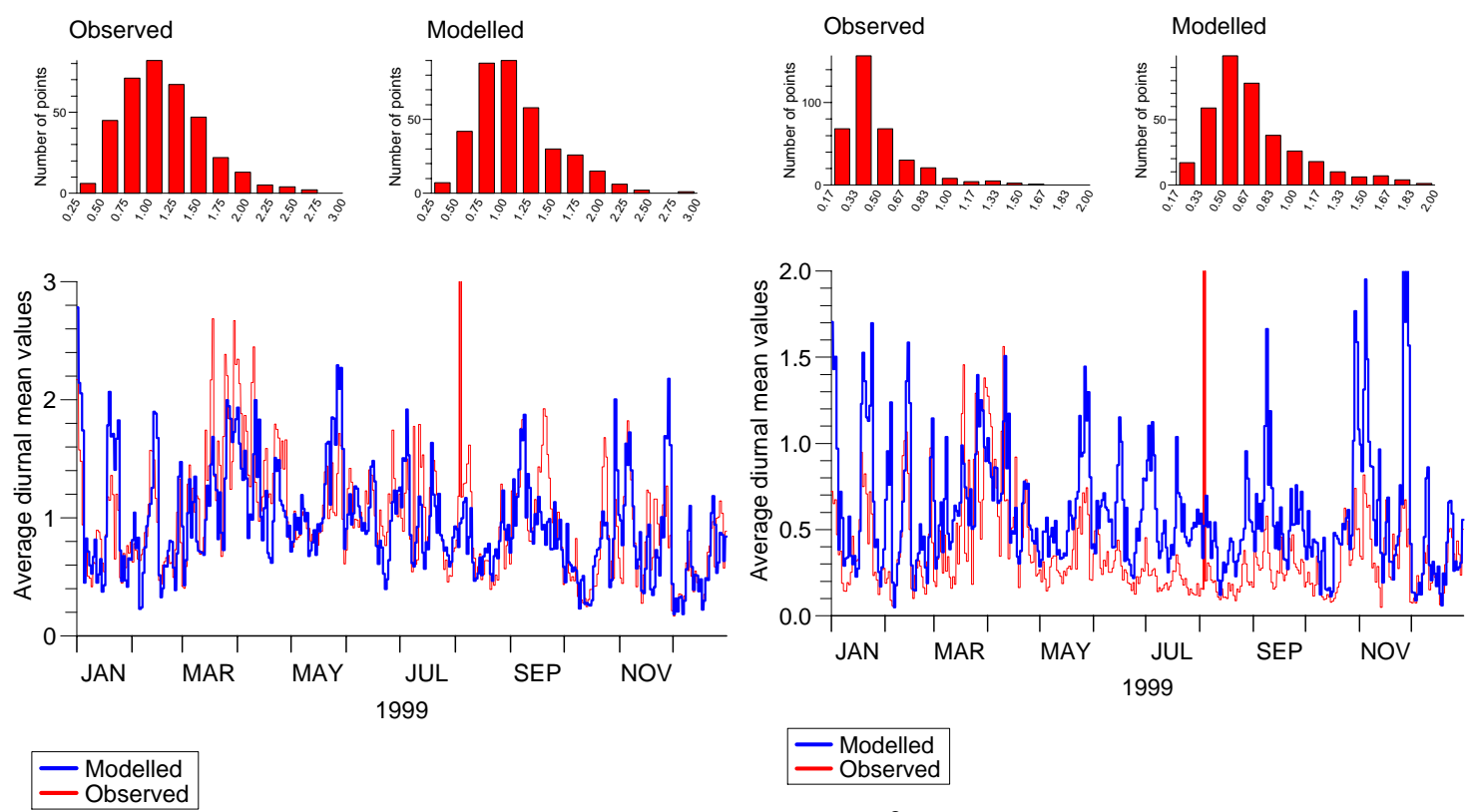

- Modelled

$$
\mathrm{HNO}_{3}+\mathrm{NO}_{3}^{-}\left(\mu \mathrm{g} \mathrm{N} / \mathrm{m}^{3}\right)
$$

\section{$\mathrm{NO}_{2}\left(\mu \mathrm{g} \mathrm{N} / \mathrm{m}^{3}\right)$}
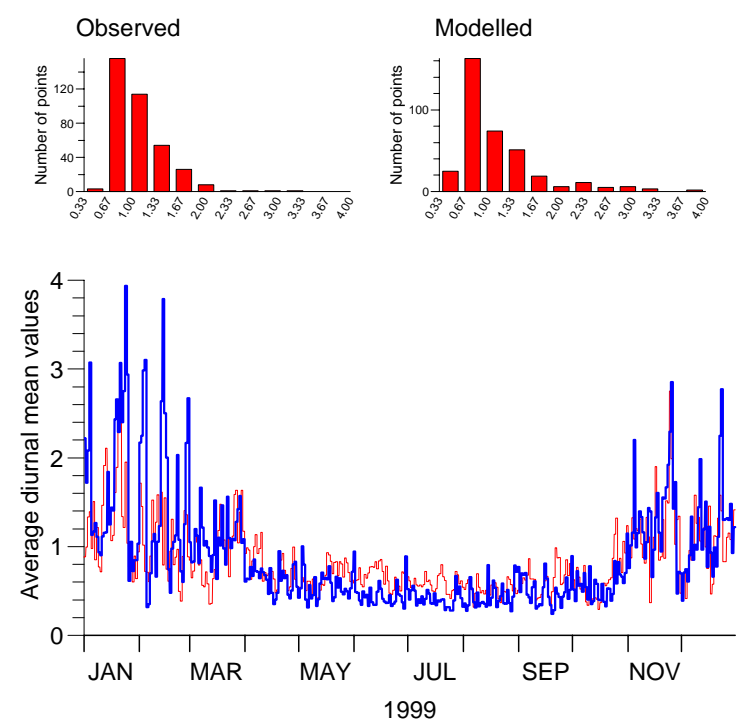

\section{- Modelled}

Fig. 5. Comparison of average concentrations of $\mathrm{NH}_{\mathrm{X}}$ ( sum of $\mathrm{NH}_{3}$ and $\mathrm{NH}_{4}^{+}$), total nitrate (sum of $\mathrm{HNO}_{3}$ and $\mathrm{NO}_{3}^{-}$) and $\mathrm{NO}_{2}$ for diurnal mean values - all data for the year 1999. The averaging is performed over the 16 selected EMEP stations for each set of data.

underestimation (in average also about 20\%). The same tendency is seen for the amount of wet deposition of the two compounds (Fig. 4).

\subsection{Analysis of time series}

Until now observed and computed annual mean values at the EMEP monitoring stations have been compared. In the following we will focus on time series and look into the model performance evaluated for monthly and diurnal mean values. 


$$
\mathrm{NH}_{3}+\mathrm{NH}_{4}^{+}\left(\mu \mathrm{g} \mathrm{N} / \mathrm{m}^{3}\right)
$$
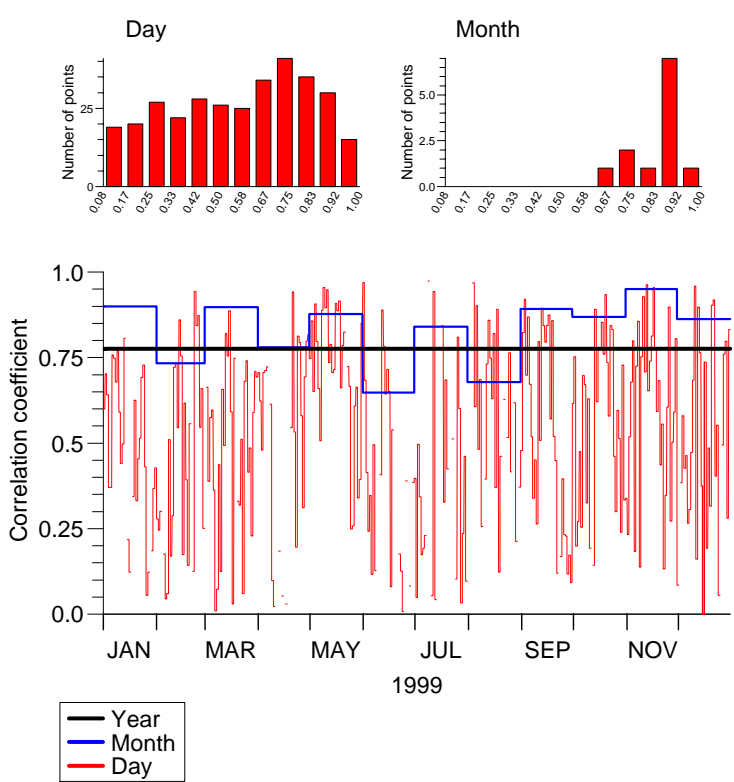

$\mathrm{HNO}_{3}+\mathrm{NO}_{3}{ }^{-}\left(\mu \mathrm{g} \mathrm{N} / \mathrm{m}^{3}\right)$
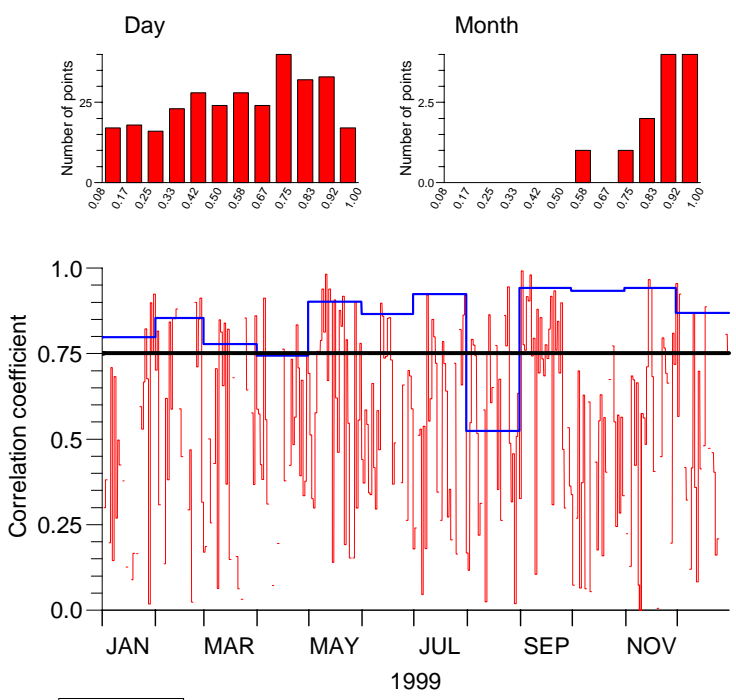

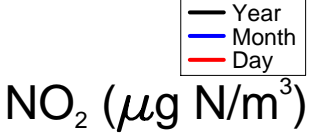
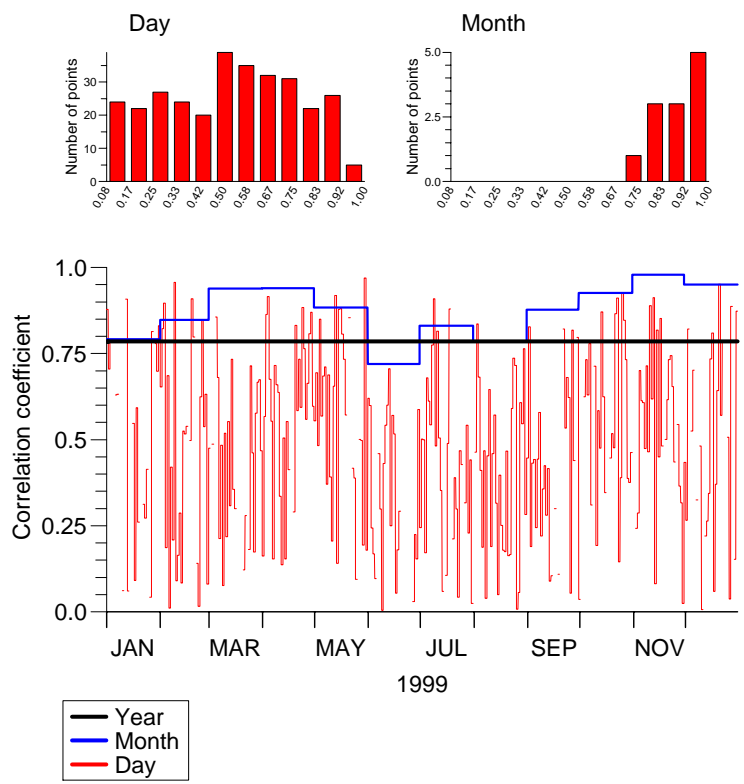

Fig. 6. Correlation coefficients between observed and modelled $\mathrm{NH}_{\mathrm{X}}$ ( $\operatorname{sum}$ of $\mathrm{NH}_{3}$ and $\mathrm{NH}_{4}^{+}$), total nitrate $\left(\right.$sum of $\mathrm{HNO}_{3}$ and $\mathrm{NO}_{3}^{-}$) and $\mathrm{NO}_{2}$ for annual, monthly and diurnal mean values - all data for the year1999. The averaging is performed over the 16 selected EMEP stations for each set of data.

Figure 5 shows observed and modelled diurnal mean concentrations of $\mathrm{NH}_{\mathrm{x}}$, total nitrate and nitrogen dioxide averaged over all available monitoring stations. $\mathrm{NH}_{\mathrm{x}}$ and nitrogen dioxide is generally well reproduced, whereas there is a general tendency to overestimate total nitrate. This result is in accordance with the comparisons performed on annual mean values for the single stations. 
$\mathrm{NH}_{4}^{+}$wet dep. $\left(\mathrm{mg} \mathrm{N} / \mathrm{m}^{2}\right)$
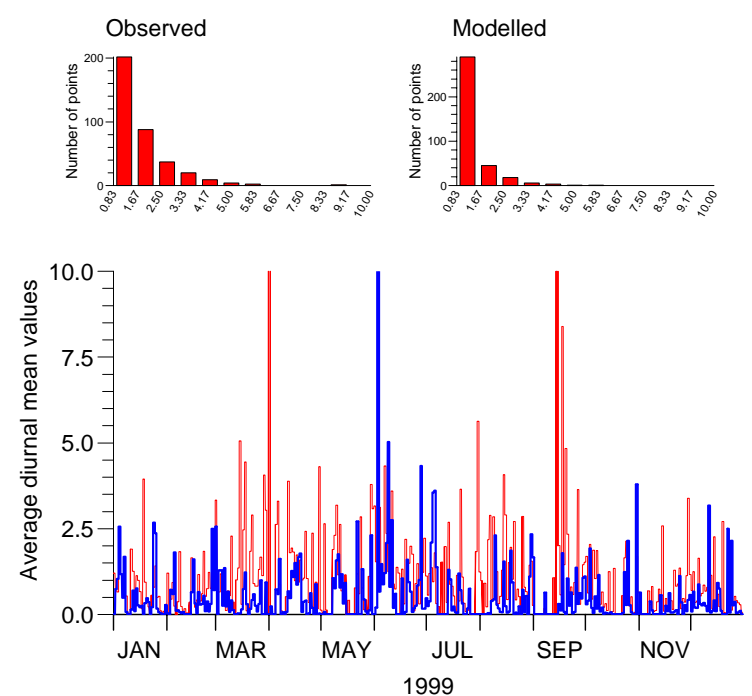

$\mathrm{NO}_{3}$ i wet dep. $\left(\mathrm{mg} \mathrm{N} / \mathrm{m}^{2}\right)$
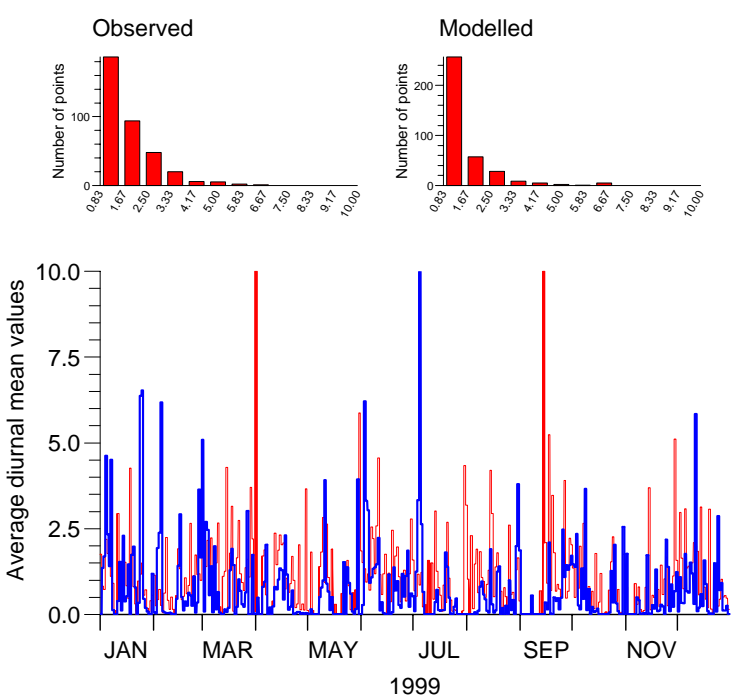

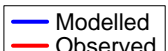

Precipitation $\left(\begin{array}{c}\bar{Z}_{\text {Modelled }} \text { Obsered } \\ \text { (mm) }\end{array}\right.$
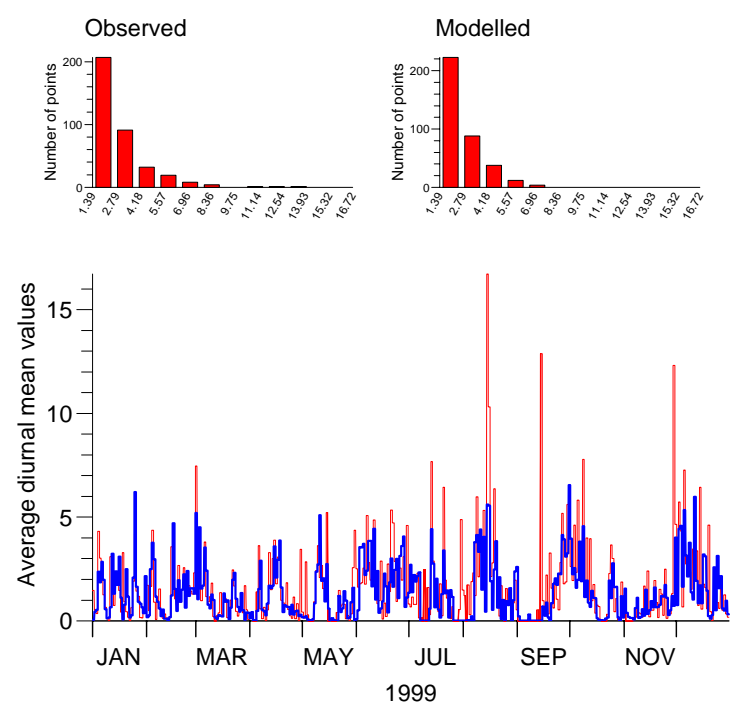

Modelled

Fig. 7. Comparison of average wet depositions of $\mathrm{NH}_{4}^{+}$and $\mathrm{NO}_{3}^{-}$, and precipitation for diurnal mean values in 1999 . The averaging is performed over the 16 selected EMEP stations for each set of data.

The analysis is expanded to investigate time series of correlation coefficients for the spatial distribution performed for the included 16 monitoring stations (see the placement of the stations in Appendix 1). Figure 6 shows the correlation between observed and modelled diurnal mean values, monthly mean values and the annual mean values. For all three species reasonably high correlation is obtained for monthly ( 0.67 to $0.9,0.56$ to 0.9 and 0.75 to 0.9 , respectively) and annual mean values $(0.77,0.75$ and 0.79 , respectively). Although some correlation (above 0.5 ) is obtained for the main part of the time, poor correlation (below 0.4) is frequently obtained when diurnal mean values are evaluated. 


$$
\mathrm{NH}_{4}^{+} \text {conc. prec. }(\mathrm{mg} \mathrm{N} / \mathrm{l})
$$
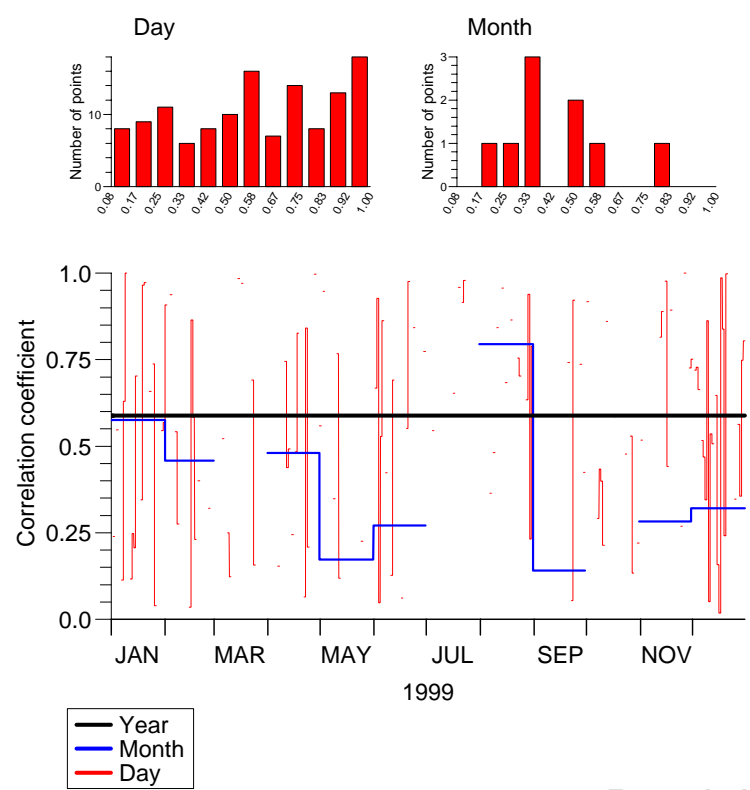

$\mathrm{NO}_{3}$ conc. prec. $(\mathrm{mg} \mathrm{N} / \mathrm{l})$
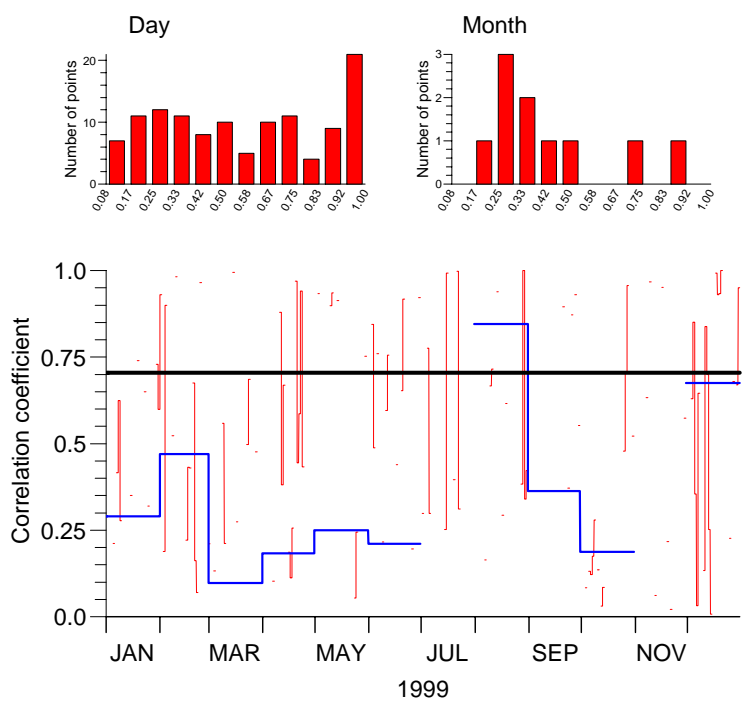
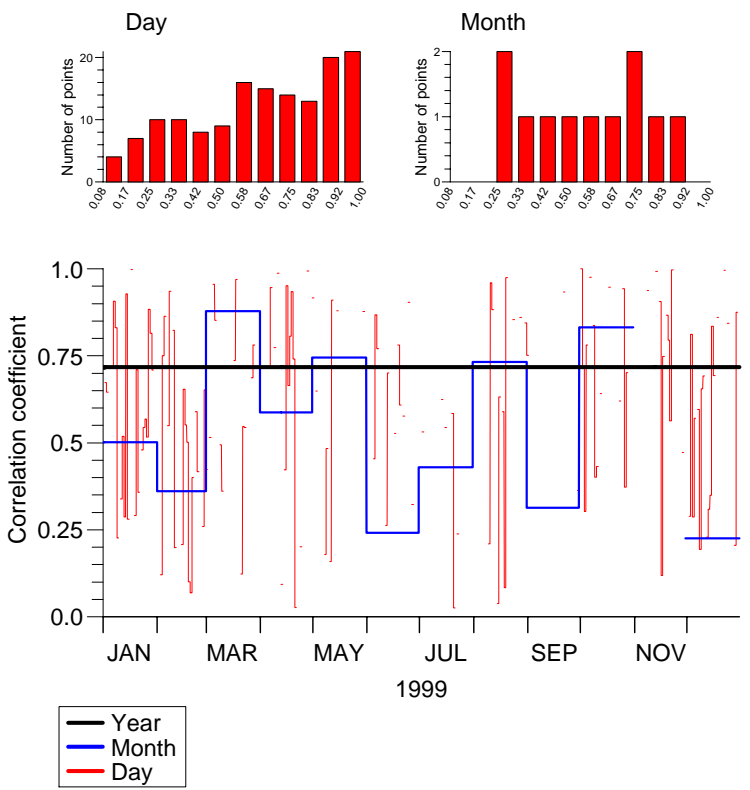

Fig. 8. Correlation coefficients for concentrations in precipitation of $\mathrm{NH}_{4}^{+}$and $\mathrm{NO}_{3}^{-}$, and precipitation for diurnal mean values for the year 1999. The averaging is performed over the 16 selected EMEP stations for each set of data. The full line represents the correlation coefficients for annual mean values.

The frequency of low nitrate and ammonium concentrations in precipitation $(<0.17 \mathrm{mg} \mathrm{N} / \mathrm{l})$ is higher in the model results than in observations (Fig. 7). For nitrate the total wet deposition is on average somewhat higher than observed due to a few modelled deposition events with high depositions (the plot is not shown here). The precipitation is in gen- eral well described by the model, although there are some of the observed episodes that are not reproduced. On annual basis the modelled and observed ammonium and nitrate wet depositions are fairly correlated $(0.58$ and 0.71$)$. Already on monthly basis the picture is considerably more scattered and on diurnal basis the results are rather poor (Fig. 8). A 

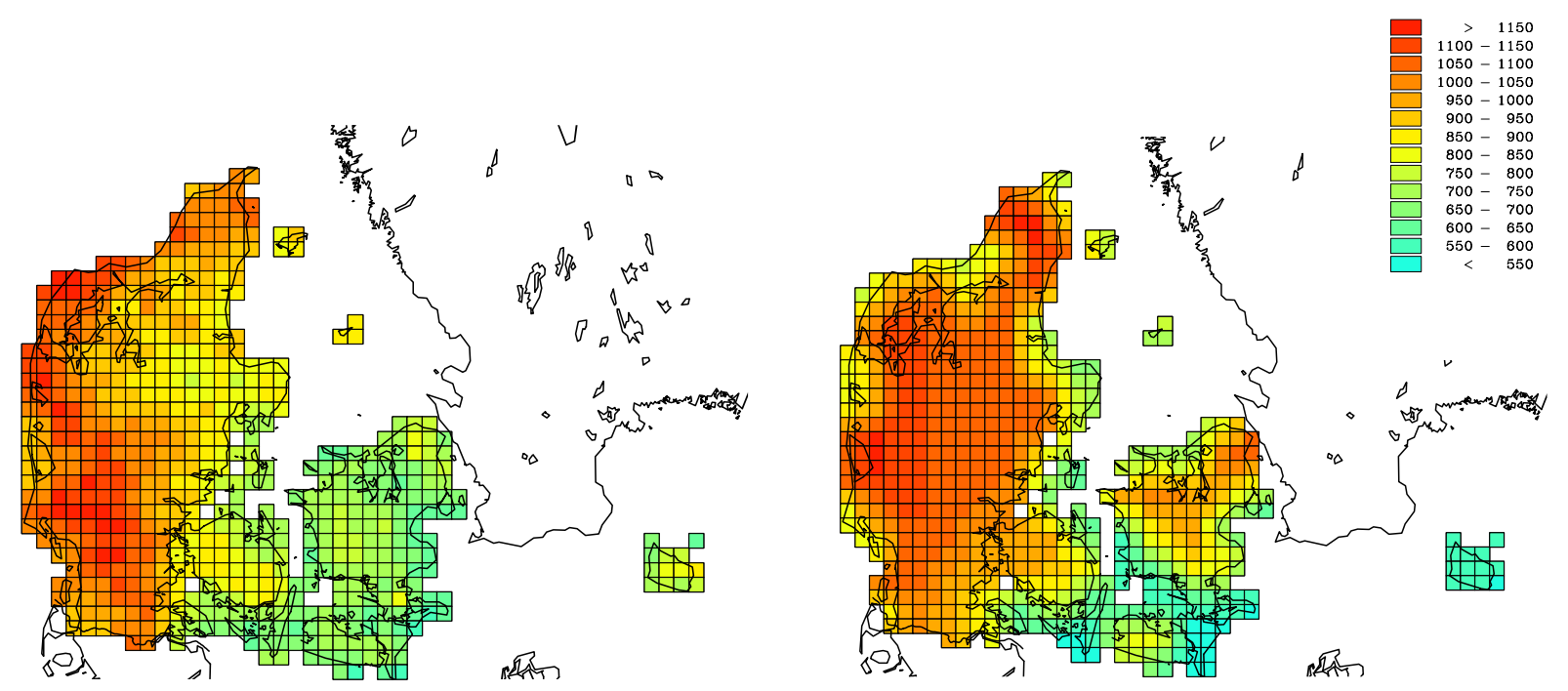

Fig. 9. Gridded annual precipitation on a $10 \mathrm{~km} \times 10 \mathrm{~km}$ grid from observed precipitation data (left) and obtained from the Eta model (right). Measurements have been provided by the Danish Meteorological Institute (Scharling, 1998).

significant part of the explanation may be found in the uncertainties in precipitation (also shown in Fig. 8). High correlations between observations and model results dominate when the annual mean values are evaluated, but even for monthly values a significant part of the results have correlations below 0.4 .

\subsection{Discussion of model performance}

The model still resolves poorly wet depositions on short averaging times like diurnal means. It is likely that dry depositions are similarly uncertain, although a high correlation between observed and modelled ambient air concentrations is generally obtained. Several explanations may be given for this discrepancy of which the most important are believed to be uncertainties in:

- The emission data used for the model calculations,

- The precipitation data from the forecast model,

- The parameterisation of dry deposition processes,

- The parameterisation of aerosol processes,

- Local conditions at the monitoring stations that cannot be resolved by the model, and

- General limitations associated with the principles of the applied Lagrangian model.

Considering emission data, the uncertainties in annual emissions on $50 \mathrm{~km} \times 50 \mathrm{~km}$ EMEP grid have previously been estimated by EMEP to be in the order of 30 to $40 \%$. However, even though the procedures for the submission of national emission data to the databases are well described, there are still data included in the databases that are subject to future corrections (Vestreng and Klein, 2002). These uncertainties increase further when data are distributed on sub-grid of $16.67 \mathrm{~km} \times 16.67 \mathrm{~km}$ and especially when highly simplified functions are applied for describing the seasonal and diurnal variation in emissions. Therefore, when variations in diurnal emissions are the governing factors for the variations in the diurnal concentrations, air pollution models in general will have problems reproducing these values. This is e.g. the case for ammonia in agricultural intensive areas like Denmark. Thus, we have initiated work that aim at improving the seasonal variation, especially concerning ammonia from agricultural activities.

The operational Eta model at NERI has a horizontal grid resolution at $0.25 \times 0.25^{\circ}$, which corresponds to approximately $39 \mathrm{~km}$ over Denmark. A combination of this grid resolution and the applied version of the Eta step-mountain coordinate system with 32 layers have the effect that the Danish land-masses have zero height in the Eta model. Even though Denmark is relatively flat compared to other countries, a not yet published investigation has revealed that a part of the precipitation that falls over Denmark is due to orographic effects. Figure 9 shows a comparison of gridded precipitation on $10 \mathrm{~km} \times 10 \mathrm{~km}$ provided by the Danish Meteorological Institute and similar figures obtained from the Eta model. The results show that the computed precipitation amounts are within the right order of magnitude, but the model results are more evenly distributed over the Danish land areas compared with the analysed precipitation data. The reason for this discrepancy is most probably that the surface topographic details are not sufficiently resolved in the relatively coarse resolution in the currently applied version of Eta. However, these issues are subjects of an ongoing project at NERI. The same considerations are expected to be valid for southern Sweden too, however a detailed validation has not been performed. 

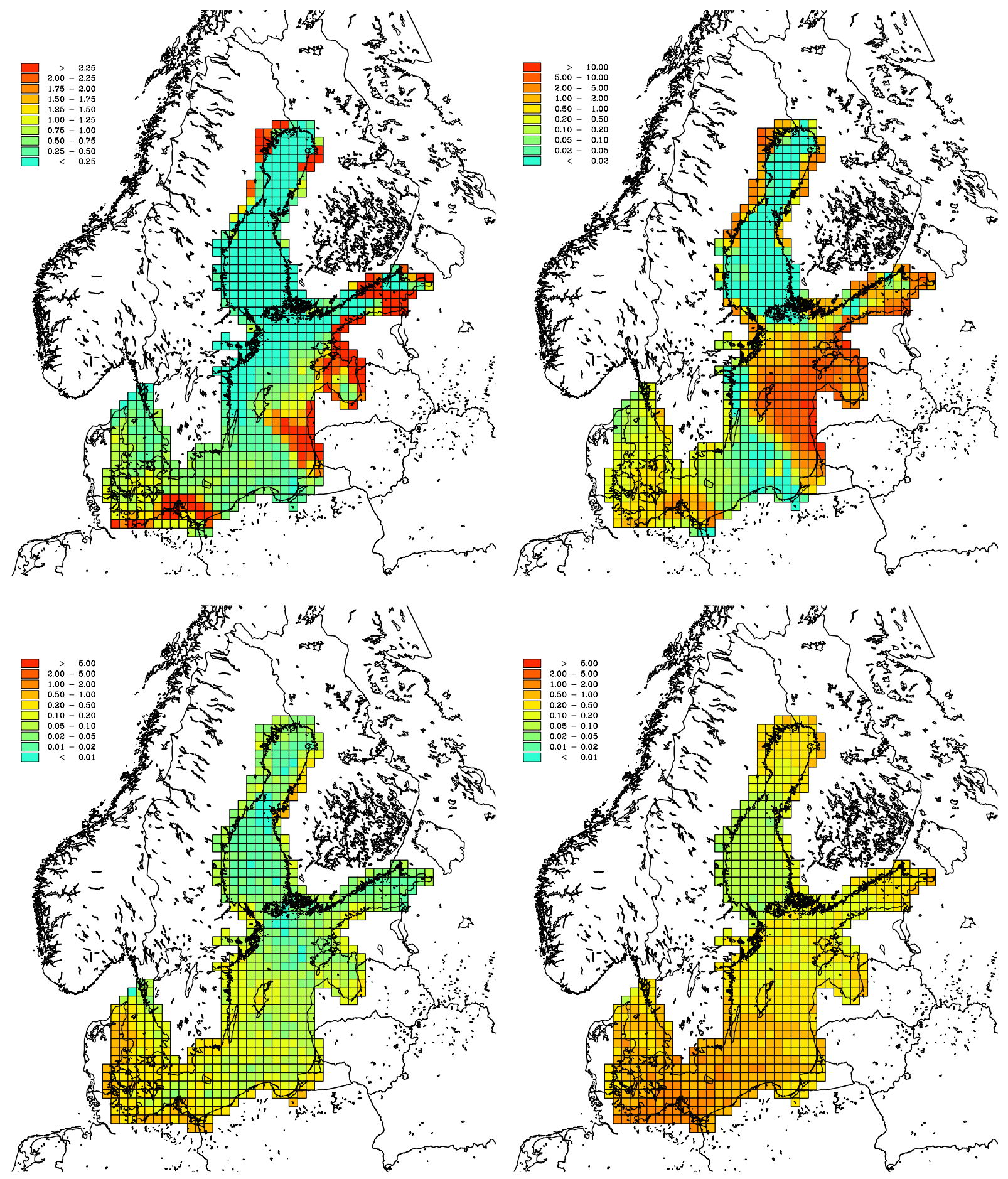

Fig. 10. Episode of high nitrogen deposition on 26 July 2002. The upper left figure shows the total nitrogen deposition $\left(\mathrm{T}\right.$ N/km $\left.{ }^{2}\right)$ on this day. The upper right figure shows the precipitation $(\mathrm{mm})$. The lower left figure shows the concentration of ammonia $\left(\mu \mathrm{g} \mathrm{N} / \mathrm{m}^{3}\right)$ and the lower right figure the concentration of particulate ammonium $\left(\mu \mathrm{g} \mathrm{N} / \mathrm{m}^{3}\right)$. 
Table 2. Comparison of the present deposition densities to the Baltic Sea with results reported elsewhere.

\begin{tabular}{lccccc}
\hline Source & Year & $\begin{array}{c}\text { Type of } \\
\text { estimate }\end{array}$ & $\begin{array}{c}\text { Dry deposition } \\
\left(\mathrm{kg} \mathrm{N} \mathrm{km}^{-2}\right)\end{array}$ & $\begin{array}{c}\text { Wet deposition } \\
\left(\mathrm{kg} \mathrm{N} \mathrm{km}^{-2}\right)\end{array}$ & $\begin{array}{c}\text { Total deposition } \\
\left(\mathrm{kg} \mathrm{N} \mathrm{km}^{-2}\right)\end{array}$ \\
\hline Rodhe et al. (1980) & 1980 & Observed & 482 & 482 & 963 \\
Ferm (1984) & $1981-1982$ & Observed & 382 & 900 & 1282 \\
FMI/Utö* & $1982-1983$ & Observed & & 780 & 790 \\
Joffre (1988) & 1983 & Modelled & & 730 & 952 \\
FMI/Utö* & $1984-1985$ & Observed & & 872 & 619 \\
HELCOM (1988) & $1983-1985$ & Observed & 80 & & 659 \\
Iversen et al. (1989) & 1985 & Modelled & & & 660 \\
Lindfors et al. (1991) & $1980-1986$ & Observed & 149 & & 601 \\
Heidam (1993) & 1988 & Modelled & & & 629 \\
Iversen et al. (1990) & 1988 & Modelled & & & 959 \\
Iversen et al. (1990) & 1989 & Modelled & & & 675 \\
Heidam (1993) & 1989 & Modelled & & & 530 \\
Asman et al. (1995) & 1990 & Modelled & 271 & & 501 \\
Heidam (1993) & 1990 & Modelled & & & 684 \\
Marmefelt et al. (1999) & 1994 & Modelled & & & \\
Tarasson and Schaug (1999) & 1997 & Modelled & & & \\
Present study & 1999 & Modelled & 150 & 534 & \\
\hline
\end{tabular}

* Refered in Lindfors et al. (1991).

\# Calculations for Kattegat only.

The current model does not take into account seasonal variation in land cover, and furthermore land use is only stratified on sea and land surfaces, where the latter is assumed covered by grass. A detailed land use database is in the process of being implemented together with surface resistances for various land use types combined with information for the entire model domain (the EMEP area) about growing seasons, type of crops etc. The model handles in general aerosol compounds in the same way as gaseous species. When dry deposition is considered, the aerosols are assumed to have a diameter of $0.8 \mu \mathrm{m}$. Transformation of gas phase compounds to aerosol compounds is parameterised in a highly simplified way. First order transformation rates are assumed for a number of compounds, whereas formation of e.g. ammonium nitrate is modelled as a function of relative humidity and gas phase concentration of nitric acid and ammonia. A new parameterisation is in process of being implemented. In this parameterisation aerosol size distributions are taken into account, and this is likely to improve the model performance although many parameters need to be determined in this context.

The current model version has 6-hourly arrival times for the trajectories, and the points along the trajectories are calculated for every $2 \mathrm{~h}$. Thus, it is assumed that using only 6hourly arrival times at 00:00, 06:00, 12:00, and 18:00 values will produce a reasonable estimate of a diurnal mean value. This may under certain circumstances not be valid. Therefore, a higher time resolution may improve the model performance, at the cost of an increase in computer calculation time. However, the present model set up is limited by the fact that the results of the calculations must be available at 06:00 each morning from the THOR system. Depositions are interpolated between arrival times, which especially for wet depositions may lead to considerable errors. The movement of the air column along the trajectory is also computed from interpolation between the calculated 2-hourly points. Close to arrival at the receptor point this may lead to uncertainties in the received emissions.

The wet deposition processes are parameterised using a commonly applied method. However, a more precise way to compute wet depositions could be obtained by implementing physical and chemical cloud droplet processes directly. However, this requires a full 3-D model that includes both meteorological processes and air pollution processes in one coupled system. The clear disadvantage of such a system is the tremendous computer resource demand, which means that this type of model usually is applied for studying only short time periods (Carmichael et al., 1991; von Salzen and Schlünzen, 1999; Kim and Cho, 1999; Hogrefe et al., 2001).

The mainly coastal monitoring stations used in the analysis of the model performance may in some cases be influenced by very local conditions that cannot be resolved in the current version of the model system. One example is the generation of sea breeze circulation cells that is not resolved in the meteorological data from the Eta model in the present application, and thus cannot be reflected in the computed nitrogen depositions either. Another issue regarding the comparison of calculations and observations is that the model 


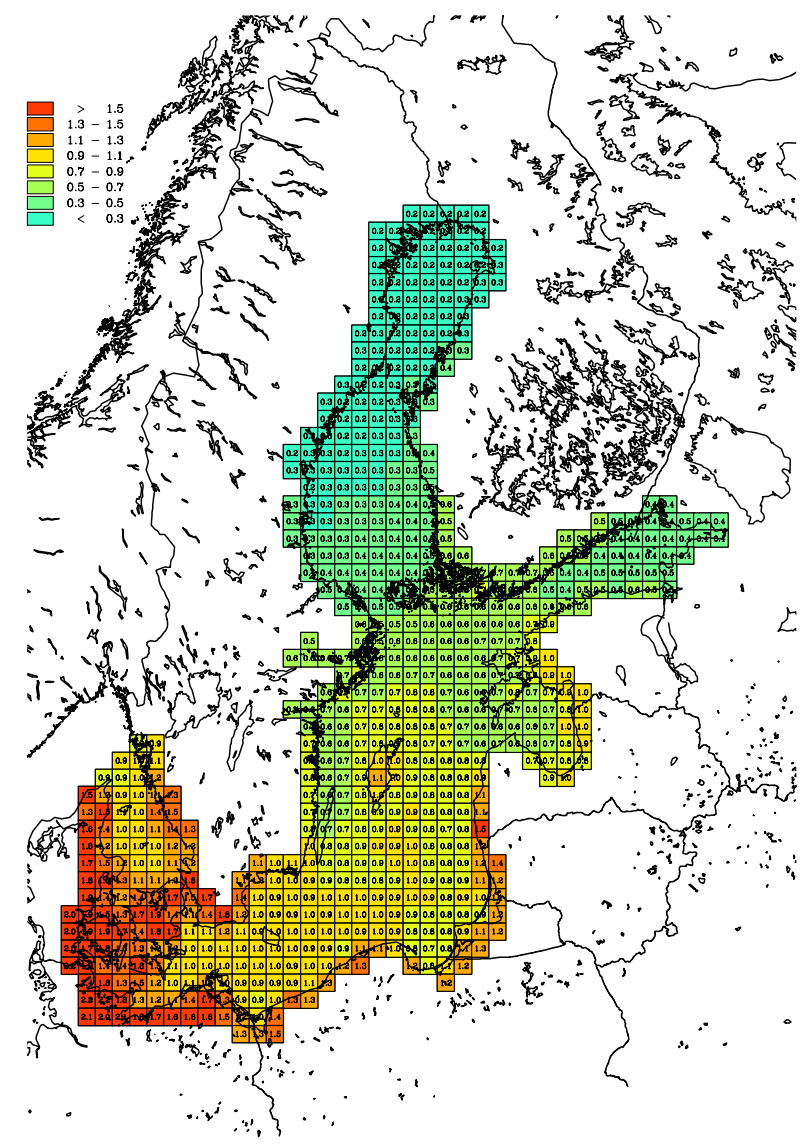

Fig. 11. Calculated nitrogen deposition $\left(\mathrm{T} \mathrm{N} \mathrm{km}^{-2}\right)$ to the entire Baltic Sea in 1999.

represents an average condition over a certain area (in this case $30 \mathrm{~km} \times 30 \mathrm{~km}$ ), whereas the observations reflect the local conditions at a specific point. This may especially affect the wet depositions, since the precipitation amount may vary up to a factor of five or more within few kilometres. In some cases a specific rain event may pass close by the monitoring station, but without contributing at all to what is collected in the bulk sampler.

The Lagrangian model type has the advantage to have relatively low computer demands, especially when a limited number of receptor points are considered. Furthermore the model scale may be changed along the trajectory, e.g. allowing for higher resolution in input data when the air parcel is approaching the receptor point. However, the uncertainty in the description of the transport may be significant in this type of models, especially considering the first part of the $96 \mathrm{~h}$ back-trajectory. Furthermore, wind turning with height is disregarded in the model, which may be a rather crude assumption. The next generation of nitrogen deposition model at NERI will therefore be a nested grid 3-dimensional Eulerian model with high spatial and temporal resolution (Frohn et al., 2001; 2002).

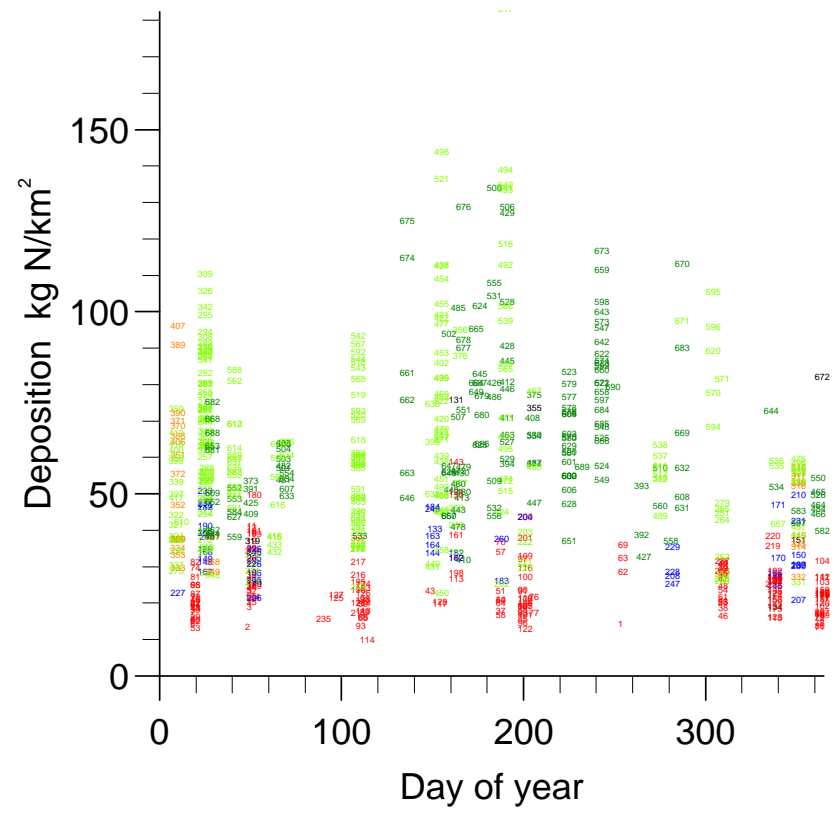

Fig. 12. Calculated maximum diurnal nitrogen deposition density $\left(\mathrm{kg} \mathrm{N} \mathrm{km}^{-2}\right)$ to 690 receptor points distributed over the entire Baltic Sea in 1999. The numbers in the plot refer to the receptor grid number, which starts in the most northern part of the Baltic and ends with the Danish waters. Red colour indicates Botvian Sea and Botvian Bay, blue indicate Gulf of Finland, orange indicate Gulf of Riga, yellow-green indicate Baltic proper (exclusive Danish waters) and dark green indicate Danish waters.

\section{Nitrogen depositions to the Baltic Sea}

The performed model calculations show a total nitrogen deposition in the year 1999 to the entire Baltic Sea of about $317.8 \mathrm{kT} \mathrm{N}$ to an area of $464406 \mathrm{~km}^{2}$. This may be compared with model results and measurements from other sources. Model calculations performed with the Swedish MATCH model gave a considerably lower value of $220 \mathrm{kT} \mathrm{N}$ for the year 1994 (Marmefelt et al., 1999) and EMEP model results have shown values of $285.4 ; 261.2$ and $280.3 \mathrm{kT} \mathrm{N}$ for the years 1988, 1989 and 1990, respectively (Heidam, 1993). However, both the MATCH model study and EMEP report an area for the Baltic Sea on only $415000 \mathrm{~km}^{2}$. Up scaling to an area of $464406 \mathrm{~km}^{2}$, the EMEP estimates show 318.7, 291.8 and 313.0 kT N for 1988, 1989 and 1990, respectively. A more recent estimate from EMEP says $208 \mathrm{kT}$ N for 1997 (Tarrasón and Schaug, 1999), which up scaled to the area used in the present study is equal to $233 \mathrm{kT}$. The most recent value from EMEP is considerably lower (about $27 \%$ ) than the present finding, whereas the older EMEP values in general are in good agreement with the present estimate. After a similar up scaling, however, the result from the MATCH model calculations is also considerably lower (23\% lower) than the results from the present study - up scaled the MATCH model result gives $246 \mathrm{kT}$ N. The model results 
Table A1. Code of the monitoring stations used in the model validation. The code is given together with the name of the site, geographic coordinates and altitude above sea level. The geographic location of the stations is shown in Fig. A1.

\begin{tabular}{|c|c|c|c|}
\hline Site & Code & Geographic coordinates & Altitude above sea level (m) \\
\hline \multicolumn{4}{|c|}{ Country: Denmark } \\
\hline Tange & DK03 & $56^{\circ} 21^{\prime} \mathrm{N}, 9^{\circ} 36^{\prime} \mathrm{E}$ & 13 \\
\hline Keldsnor & DK05 & $54^{\circ} 44^{\prime} \mathrm{N}, 10^{\circ} 44^{\prime} \mathrm{E}$ & 9 \\
\hline Anholt & DK08 & $56^{\circ} 43^{\prime} \mathrm{N}, 11^{\circ} 31^{\prime} \mathrm{E}$ & 40 \\
\hline \multicolumn{4}{|c|}{ Country: Finland } \\
\hline Ähtäri & FI04 & $62^{\circ} 33^{\prime} \mathrm{N}, 24^{\circ} 13^{\prime} \mathrm{E}$ & 4 \\
\hline Virolahti II & FI17 & $60^{\circ} 31^{\prime} \mathrm{N}, 27^{\circ} 41^{\prime} \mathrm{E}$ & 4 \\
\hline \multicolumn{4}{|c|}{ Country: Lithuania } \\
\hline Preila & LT15 (SU15) & $55^{\circ} 21^{\prime} \mathrm{N}, 21^{\circ} 04^{\prime} \mathrm{E}$ & 5 \\
\hline \multicolumn{4}{|c|}{ Country: Latvia } \\
\hline Rucava & LV10 (SU10) & $56^{\circ} 13^{\prime} \mathrm{N}, 21^{\circ} 13^{\prime} \mathrm{E}$ & 18 \\
\hline \multicolumn{4}{|c|}{ Country: Poland } \\
\hline Leba & PL04 & $54^{\circ} 45^{\prime} \mathrm{N}, 17^{\circ} 32^{\prime} \mathrm{E}$ & 2 \\
\hline Diabla Gora & PL05 & $54^{\circ} 09^{\prime} \mathrm{N}, 22^{\circ} 04^{\prime} \mathrm{E}$ & 157 \\
\hline \multicolumn{4}{|c|}{ Country: Sweden } \\
\hline Rörvik & SE02 & $57^{\circ} 25^{\prime} \mathrm{N}, 11^{\circ} 56^{\prime} \mathrm{E}$ & 10 \\
\hline Hoburg & SE08 & $56^{\circ} 55^{\prime} \mathrm{N}, 18^{\circ} 09^{\prime} \mathrm{E}$ & 58 \\
\hline Vavihill & SE11 & $56^{\circ} 01^{\prime} \mathrm{N}, 13^{\circ} 09^{\prime} \mathrm{E}$ & 172 \\
\hline Aspvreten & SE12 & $58^{\circ} 48^{\prime} \mathrm{N}, 17^{\circ} 23^{\prime} \mathrm{E}$ & 20 \\
\hline \multicolumn{4}{|c|}{ Country: Estonia } \\
\hline Lahemaa & EE09 (SU09) & $59^{\circ} 30^{\prime} \mathrm{N}, 25^{\circ} 54^{\prime} \mathrm{E}$ & 32 \\
\hline Vilsandi & EE11 (SU11) & $58^{\circ} 23^{\prime} \mathrm{N}, 21^{\circ} 49^{\prime} \mathrm{E}$ & 6 \\
\hline \multicolumn{4}{|c|}{ Country: Germany } \\
\hline Zingst & DE09 & $54^{\circ} 26^{\prime} \mathrm{N}, 12^{\circ} 44^{\prime} \mathrm{E}$ & 1 \\
\hline
\end{tabular}

in the present study gives an average deposition for 1999 of about $684 \mathrm{~kg} \mathrm{~N} \mathrm{~km}^{-2}$ of which wet deposition accounts for about $78 \%$. It should be noted that at least for Danish marine waters 1997 was a relatively dry year compared with 1999 , and this may explain a considerable part of the differences in the estimates. Ellermann et al. (2002) reported a precipitation of $520 \mathrm{~mm}$ in 1997 and 780 in 1999 at the island Anholt in the middle of the Kattegat Strait. Furthermore, years with low precipitation also have a low net nitrogen deposition and years with high precipitation are years with high total nitrogen deposition (Ellermann et al., 2002). Reported studies on atmospheric nitrogen deposition to the Baltic in general show a contribution from wet deposition on the order of $70-80 \%$ (Table 2), which is in very good agreement with the present results. The reported studies show depositions in the range 600 to $1300 \mathrm{~kg} \mathrm{~N} \mathrm{~km}^{-2}$, where the highest values refer to the 1980'ties. Taking into account that concentrations of aerosol bound nitrogen compounds have decreased some $30 \%$ over that time period, the present results are in good agreement with previous studies, since the highest values are reported for the 1980'ties and early 1990'ties.

Episodes of high atmospheric nitrogen deposition are solely the result of precipitation events. Depositions may be somewhat elevated close to the coast when transport from nearby agricultural activities lead to high ammonia concentrations. However, the resulting dry deposition is considerably smaller than what is observed from rain out of aerosol phase ammonium and nitrate. Figure 10 shows the simulation of an event with high local wet deposition of atmospheric nitrogen in a belt from the coast of Poland and out to Gotland in the Baltic Sea. When the different plots are compared it is clear that the high deposition appears where there is an overlap between high aerosol phase concentrations and high precipitation amounts.

The computed total atmospheric nitrogen deposition to the Baltic Sea in 1999 is shown in Fig. 11. The deposition has 


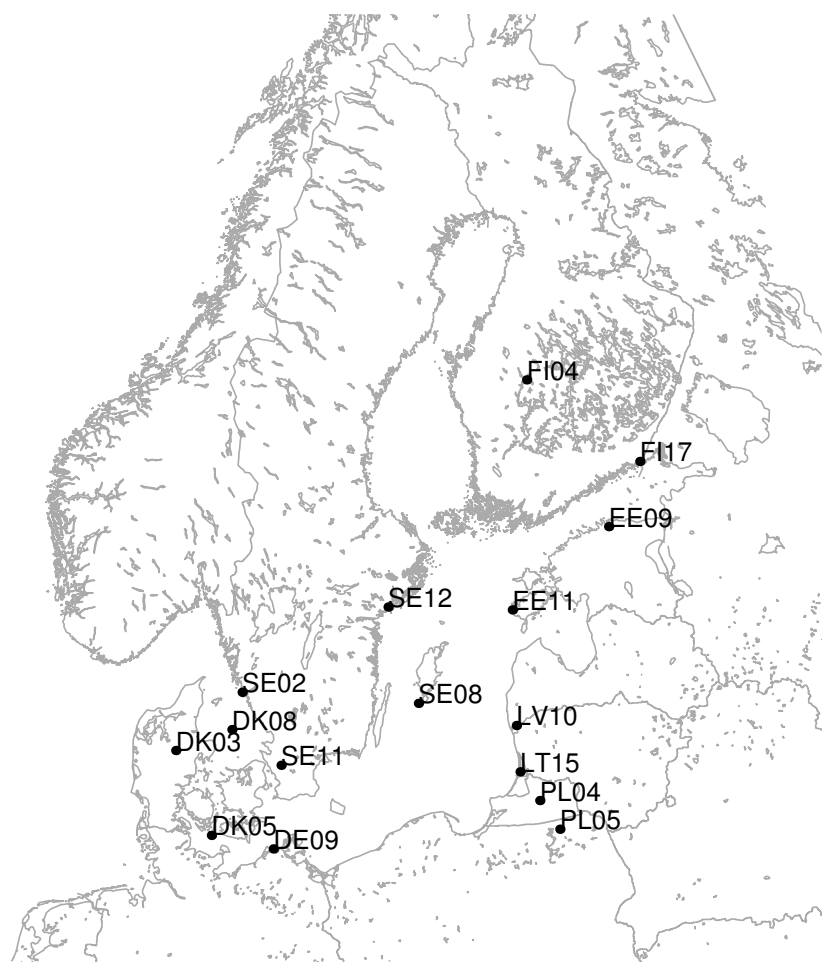

Fig. A1. Geographic location of the monitoring stations used in the model validation. The names of the sites, the geographic coordinates and the altitude above sea level are given in Table A1.

a pronounced south-north gradient with depositions in the range about $1000 \mathrm{~kg} \mathrm{~N} \mathrm{~km}^{-2}$ in south and $200 \mathrm{~kg} \mathrm{~N} \mathrm{~km}^{-2}$ in north. This gradient is due to transport from the areas with high emission density in the northern part of the European continent. Tarrasón and Schaug (1999) reported below $100 \mathrm{~kg} \mathrm{~N} \mathrm{~km}^{-2}$ in the north and between 400 and 700 in the south, but again it should be noted that these values related to 1997 , where precipitation about over Danish waters were considerably lower than in 1999.

According to the model results for episodes, the maximum diurnal depositions over the Danish waters took place in the mid summer period where the algae growth is high (Fig. 12). For the northern part of the Baltic maximum values were distributed over most of the year. These results are again strongly dependent on the prediction of precipitation events and therefore rather uncertain.

\section{Conclusions}

The aim of the evaluation of the model performance was here to investigate how well the model reproduces air concentrations and wet depositions when short averaging times are considered. The analysis has shown that the model reproduces reasonably well annual and monthly mean ambient air concentrations. Diurnal mean concentrations of $\mathrm{NH}_{\mathrm{x}}$ (sum of $\mathrm{NH}_{3}$ and $\mathrm{NH}_{4}^{+}$) and $\mathrm{NO}_{2}$ are fairly well reproduced, whereas total nitrate (sum of $\mathrm{HNO}_{3}$ and $\mathrm{NO}_{3}^{-}$) is somewhat overestimated by the model. Wet depositions of nitrate and ammonia are fairly well described for annual mean values, whereas the uncertainty is high for the monthly mean values and the wet deposition is poorly described for diurnal mean values. The model calculations show that annual nitrogen depositions to the Baltic are in the range from $1000 \mathrm{~kg} \mathrm{~N} \mathrm{~km}^{-2}$ in the south to $200 \mathrm{~kg} \mathrm{~N} \mathrm{~km}^{-2}$ in the north, with an overall load of $318 \mathrm{kT}$ $\mathrm{N}$ in 1999 to an area of $464406 \mathrm{~km}^{2}$. The present finding of the overall load is somewhat higher than what is found in literature, but this may be partly due to differences between years. The present result is for the year 1999, where high precipitation amounts are reported for the Danish marine waters, whereas literature values all refer to years before 1998. Maximum diurnal depositions in 1999 seem to appear in the summer period for the Danish waters, but seem also to appear at any time of year for the rest of the Baltic. This result is quite uncertain and may only apply to this specific year.

\section{Appendix A: Monitoring stations used in the model vali- dation}

The following EMEP monitoring stations were included in the model validation for the year 1999 (further information may be obtained from http://www.nilu.no/projects/ccc/index. $\mathrm{html})$. The station codes in Table A1 are used in several of the plots and the geographic location of the stations is shown in Fig. A1.

Acknowledgements. The Nordic Council of Ministers funded the presented work as part of the project 00/01 NO COMMENTS (http: //www.imr.no/ $\sim$ morten/nocomments/). Measurements from EMEP monitoring stations around the Baltic Sea in 1999 have been obtained from the web at the Norwegian Institute for Air Research (http://www.nilu.no/projects/ccc/emepdata.html). S. Reis and U. Schwarz, University of Stuttgart provided detailed emission data from the EUROTRAC GENEMIS project for the EU countries.

\section{References}

Asman, W. A. H., Berkowicz, R., Christensen, J., Hertel, O., and Runge, E. H.: Atmospheric Contribution of nitrogen species to Kattegat (In Danish: Atmosfærisk tilførsel af kvælstofforbindelser til Kattegat). Under the Series "Marine Research from the Danish Environmental Protection Agency", No. 37, Danish Environmental Protection Agency, Copenhagen, Denmark, 1994.

Asman, W. A. H., Hertel, O., Berkowicz, R., Christensen, J., Runge, E.H., Sørensen, L. L., Granby, K., Nielsen, H., Jensen, B., Gryning, S. E., Sempreviva, A. M., Larsen, S., Hummelshøj, P., Jensen, N. O., Allerup, P., Jørgensen, J., Madsen, H., Overgaard, S., and Vejen, F.: Atmospheric Nitrogen Input to the Kattegat Strait, Ophelia, 42, 5-28, 1995.

Ambelas Skjøth, C., Hertel, O., and Ellermann, T.: Use of a Trajectory Model in the Danish nation-wide background Programme, Phys. Chem. Earth., 27, 35, 1469-1477, 2002. 
Berkowicz, R., Hertel, O., Sørensen, N. N., and Michelsen, J. A.: Modelling Air Pollution from Traffic in Urban Areas, in proceedings from IMA meeting on "Flow and Dispersion Through Obstacles", Cambridge, England, 28 to 30 March, 1994, edited by Perkins, R. J. and Belcher, S. E., 121-142, 1997.

Berkowicz, R.: A simple model for urban background pollution, Environmental Monitoring and Assessment, 65, 259-267, 2000a.

Berkowicz, R.: OSPM - a parameterised street pollution model, Environmental Monitoring and Assessment, 65, 323-331, $2000 \mathrm{~b}$.

Brandt, J., Christensen, J. H., Frohn, L., Berkowicz, R., and Palmgren, F.: The DMU-ATMI THOR air pollution forecast system system description. Technical Report from NERI No. 321, National Environmental Research Institute, PO Box 358, Frederiksborgvej 399, DK-4000 Roskilde, Denmark, 60, http://www.dmu. dk/1_viden/2_Publikationer/3_fagrapporter/default.asp 2000.

Brandt, J., Christensen, J. H., Frohn, J. M., Palmgren, F., Berkowicz, R., and Zlatev, Z.: Operational air pollution forecasts from European to local scale, Atmos. Environ., 35, 1, S91-S98, 2001 a.

Brandt, J., Christensen, J. H., Frohn, L. M., and Berkowicz, R.: Operational air pollution forecast from regional scale to urban street scale, Part 1: system description, Physics and Chemistry of the Earth (B), 26, 10, 781-786, 2001b.

Brandt, J., Christensen, J. H., and Frohn, L. M.: Operational air pollution forecast from regional scale to urban street scale. Part 2: performance evaluation, Physics and Chemistry of the Earth (B), 26, 10, 825-830, 2001c.

Brutsaert, W. H.: Evaporation into the Atmosphere, Reidel, Boston, 1982.

Carmichael, G. R., Peters, L. K., and Saylor, R. D.: The STEM-II regional scale acid deposition and photochemical oxidant model 1 and overview of model development and applications, Atmospheric Environment Part A - General Topics, 25, 10, 20772090, 1991.

Ellermann, T., Hertel, O., Munies, C., and Kemp, K.: NOVA 2003, Atmospheric Deposition 2001 (In Danish: NOVA 2003, Atmosfrisk deposition 2001), Danish National Environmental Research Institute, PO Box 358, Frederiksborgvej 399, 4000 Roskilde, Denmark, Technical Report, 418, 82, http://www.dmu.dk/1_viden/2_Publikationer/3_fagrapporter/ rapporter/FR418.pdf, 2002.

EMEP, Estimates of airborne transboundary transport of sulphur and nitrogen over Europe, EMEP/MSC-W Report 1/88, Oslo, Norway, 79, 1988.

Frohn, L. M., Christensen, J. H., and Brandt, J.: Development of a regional high resolution air pollution model - The numerical approach, J. Comp. Phys., 179, 68-92, 2002.

Frohn, L. M., Christensen, J.H., Brandt, J., and Hertel, O.: Development of a high resolution integrated nested model for studying air pollution in Denmark, Physics and Chemistry of the Earth (B), 26, 10, 769-774, 2001.

Gery, M. W., Whitten, G. Z., and Killus, J. P.: Development and testing of the CBM-IV for urban and regional modeling. EPA600/3-88-012 US EPA, Research Triangle Park, N.C., 1989a.

Gery, M. W., Whitten, G. Z., Killus, J. P., and Dodge, M. C.: A photochemical kinetics mechanism for urban and regional scale computer modeling, J. Geophys. Res., 94D, 12 925-12 956, 1989b.

Hanna, S. R., Briggs, G. A., and Hosker Jr., R. P.: Handbook on Atmospheric Diffusion, Technical Information Center, U.S. De- partment of Energy, 102, 1982.

Heidam, N. Z.: Nitrogen deposition to the Baltic Sea: Experimental and model estimates, Atmos. Environ., 27A, 6, 815-822, 1993.

HELCOM: Baltic Marine Environment Protection Commission: deposition estimates to the Baltic Sea area based on reported data for 1983-1985 edited by Söderlund, R. and Areskoug, H., Reprints Copy, 25, 1988.

Hertel, O., Berkowicz, R., Christensen, J., and Hov, Ø.: Tests of two Numerical Schemes for use in Atmospheric Transport-Chemistry models, Atmos. Environ., 27A, 16, 2591-2611, 1993.

Hertel, O., Christensen, J., Runge, E. H., Asman, W. A. H., Berkowicz, R., Hovmand, M. F., and Hov, Ø.: Development and Testing of a new Variable Scale Air Pollution Model - ACDEP, Atmos. Environ., 29, 11, 1267-1290, 1995.

Hertel, O., Ambelas Skjøth, C., Frohn, L. M., Vignati, E., Frydendall, J., de Leeuw, G., Swarz, S., and Reis, S.: Assessment of the Atmospheric Nitrogen and sulphur Inputs into the North Sea using a Lagrangian model, Phys. Chem. Earth, 27, 35), 1507-1515, 2002.

Hogrefe, C., Rao, S. T., Kasibhatla, P., Hao, W., Sistla, G., Mathur, R., and McHenry, J.: Evaluating the performance of regional.scale photochemical modeling system: Part II - ozone predictions, Atmos. Environ., 35, 24, 4175-4188, 2001.

Huang, H-C. and Chang, J.: On the performance of numerical solvers for a chemistry submodel in three-dimensional air quality models, I. Box model simulations, J. Geophys. Res., 106, D17, $20175-20188,2001$.

Iversen, T., Saltbones, J., Sandnes, H., Eliasen, A., and Hov, Ø.: Airborne transboundary transport of sulphur and nitrogen over Europe - Model description and calculations, EMEP MSC-W Report 2/89, 92, 1989.

Iversen, T., Halvorsen, N. E., Saltbones, J., and Sandnes, H.: calculated budgets for airborne sulphur and nitrogen in Europe, EMEP MSC-W Report 2/90, 142, 1990.

Joffre, S.: Parameterisation and assessment of processes affecting the long-range transport of airborne pollutants to the sea, Finnish Meteorological Institute Contribution No. 1, 49, 1988.

Kim, J. and Cho, S. Y.: Application of the nested grid STEM to an early summer acid rain in South Korea, Atmos. Environ., 33, 19, 3167-3181, 1999.

Larsson, U., Elmgren, R., and Wulff, F.: Eutrophication and the Baltic Sea, Causes and consequences, Ambio, 14, 9-14, 1985.

Lindfors, V., Joffre, S. M., and Damski, J.: Determination of the wet and dry deposition of sulphur and nitrogen conpounds over the Baltic Sea using actual meteorological data, Finish Meteorological Institute Contributions No. 4, Helsinki, Finland, 111, 1991.

Lindfors, V., Joffre, S., and Damski, J.: Meteorological variability of the wet and dry deposition of sulphur and nitrogen compounds over the Baltic Sea, Water, Air, and Soil Pollution, 66, 1-28, 1993.

Marmefelt, E., Arheimer, B., and Langner, J.: An integrated biogeochemical model system for the Baltic Sea, Hydrobiologia, 393, 45-56, 1999.

Meyer-Reil, L.-A., and Köster, M.: Eutrophication of Marine Waters: Effects on Benthic Microbial Communities, Marine Pollution Bulletin, 41, 1-6,, 255, 263, 2000.

Møhlenberg, F.: Effects of meteorology and nutrient load on oxygen depletion in a Danish micro-tidal estuary, Aquatic Ecology, 33, 
55-64, 1999.

Nickovic, S., Michailovic, D., Rajkovic, B., and Papdopulus, A.: The weather Forecasting System SKIRON II, Description of the model, June, Athens, 228, 1998.

Paerl, H. W.: Coastal eutrophication in relation to atmospheric deposition: current perspectives, Ophelia, 41, 237-259, 1995.

Rodhe, H., Söderlund, R., and Ekstedt, J.: Deposition of airborne pollutants on the Baltic, Ambio, 9, 3:4, 168-173, 1980.

Sandnes, H.: Calculated budgets for airborne acidifying components in Europe, 1985, 1987, 1988, 1989, 1990, 1991 and 1992, EMEP MSC-W Report 1/93, Norwegian Meteorological Institute, PO Box 43, N-0313, Oslo, Norway, 1993.

Scharling, M.: Climatic grit Denmark, Precipitation $10 \mathrm{~km} \times 10 \mathrm{~km}$, Description of Methods, in Danish: Klimagrid Danmark, Nedbør $10 \mathrm{~km} \times 10 \mathrm{~km}$, Metodebeskrivelse), Danish Meteorological Institute, Ministry of Transport, Copenhagen, Technical Report 9817, 16, 1998.

Slinn, S. A. and Slinn, W. G. B.: Predictions for particle deposition on natural waters, Atmos. Environ., 14, 1013-1016, 1980.

Spokes, L., Jickells, T., Rendell, A., Schulz, M., Rebers, A., Dannecker, W., Krüger, O., Lermakers, M., and Baeyens, W.: High Atmospheric Nitrogen Deposition Events Over the North Sea, Marine Pollution Bulletin, 26, 12, 698-703, 1993.

Spokes, L., Yeatman, S. G., Cornell, S. E., and Jickells, T.: Nitrogen deposition to the eastern Atlantic Ocean, The importance of south-easterly flow, Tellus, 52B, 37-49, 2000.

Tarrasón, L. and Schaug, J. (Eds.): Transboundary acid deposition in Europe, EMEP summary Report 1999, Norwegian Meteorological Institute Research Report No. 83, 70, 1999.
Tilmes, S., Brandt, J., Flatøy, F., Bergström, R., Flemming, J., Langner, J., Christensen, J. H., Frohn, L. M., Hov, Ø., Jacobsen, I., Reimer, E., Stern, R., and Zimmermann, J.: Comparison of five Eulerian ozone prediction systems for summer 1999 using the German monitoring data, J. Atmos. Chem., 42, 91-121, 2002.

Richardson, K.: Harmful or exceptional Phytoplankton Blooms in the Marine Ecosystem, Advances in marine biology, 31, 301385, 1997.

Rosenberg, R., Elmgren, R., Fleischer, S., Jonsson, P., Persson, G., and Dahlin, H.: Marine eutrophication case studies in Sweden, Ambio, 19, 102-108, 1990.

Rydberg, L., Edler, L., Floderus, S., and Granéll, W.: Interaction Between Supply of Nutrients, Primary Production, Sedimentation and Oxygen Consumption in the SE Kattegat, Ambio, 19, 3 , 134-141, 1990.

Vestreng, V. and Klein, H.: Emission data reported to UNECE/EMEP: Quality assurance and trend analysis \& presentation on WebDab. EMEP MSC-W Status report, EMEP/MSC-W Note 1, 2002.

Von Salzen, K. and Schlünzen, H.: Simulation of the dynamics and composition of secondary and marine inorganic aerosols in the coastal atmosphere, J. Geophys. Res., 104, D23, 30 201-30217, 1999.

Wesely, M. L. and Hicks, B. B.: Some factors that affects the deposition of sulphur dioxide and similar gases on vegetation, JAPCA, 27, 1110-1116, 1977.

Zlatev, Z., Christensen, J., and Hov, Ø.: A Eulerian air pollution model for Europe with nonlinear chemistry, J. Atmos. Chem., 15, 1-37, 1992. 